УДК 050(=163.41)"17/18"

821.163.41.09 Обрадовић Д.

https://doi.org/10.18485/msc50.2019.1.ch31

Миодраг Матицки

\title{
ПОЧЕЦИ СРПСКЕ КЬИЖЕВНЕ ПЕРИОДИКЕ - ДОСИТЕЈЕВ ЦВЕТНИК БАСНЕ (ЛАЈПЦИГ, 1788) У ЧАСОПИСНОМ И ЖАНРОВСКОМ КОНТЕКСТУ
}

\section{Уводне напомене}

Под утицајем протестантски усмереног просветитељства које заступа став да наука, па и тумачење Библије треба да служе потребама обичног човека, да се приближе на популаран начин (најчешће преко популарних сажетих чланака, прича из класичне старине и илустрованих библијских прича) пре свега младима (јуности), почев од Орфелиновог Славено-сербског восточне иеркве календара (Венеција, 1766), који Вук Караџић издваја као „први српски календар” и бољи од потоњих славеносербских и илирских, и Вечног, т.j. от начала до конца мира трајушчег календара (Беч, 1783; Будим, 1789), који је представљао неку врсту популарне научне енциклопедије, те Славено-сербског магазина (Венеција, I/1768) који такав став у уводнику прокламује (овај уводник Јован Скерлић назива „манифестом историјског значаја”), крећу изветници, ковчежићи, забавници, алманаси и зборници са одликама периодичних публикација.

Први српски алманаси у основи су годишњаци хибридне форме: магазини, цветници, да би тек 1815 . године, захваљујући алманасима Димитрија Давидовића, добили српско име забавник, а са периодиком Димитрија Тирола и име алманах (Банатски алманах, 1827-1829). Називи одражавају одређене аспекте ових периодика: њихову функцију (забавник), периодичност (годишњак), књижевно-уметнички карактер прилога у њима (цветник), док остали упућују на њихова основна структурно-жанровска обележја (као, на пример, песеници, лире: Србски славуј Атанасија Николића, I и II, Будим, 1927; III, 1836; Београдска лира Григорија Возаровића, Београд, 1833; Крагујевац, 1834; 1835). Посебну групу чине алманашки календари и зборници (синоним: магазин, збирка), који 
упућују на два међусобно различита типа публикација, од којих оба у извесним случајевима представљају синониме за алманах.

Прве овакве публикације, најчешће начињене по руским и немачким узорима, биле су дело једног аутора - уредника (Магазин Захарије Орфелина; Даница Вука Караџића, Беч - Будим, 1826-1829; 1834; Баков врх - забавник Лазе Нанчића, Вршац, I - III - 1883). Они у њима публикују своје списе, оригинална и преведена дела, кореспондирају са читаоцима. У почетку, у њима је највише преведених текстова, прештампавају се одломци из раније штампаних књига и плакета или рукописних верзија умножених текстова домаћих писаца, а тек касније наћи ће се у њима нови прилози домаћих писаца који се објављују први пут.

И Доситеј је свој цветник Басне (Лајпциг, 1788) најпре намеравао да објављује у свескама четири године заредом, а наменио га је образовању младих. У предговору одељку сентенција Доситеј открива да је књигу у чијем наслову доминира жанр басана начинио као иветник. Он нам том приликом чак и пружа могућу дефиницију цветника као периодичне публикације:

„Сврших басне, дај јошт које писмо; а кад и ова дођоше на крај, изиђоше преда ме некакова предивна инглиска изреченија ... Зашто не бих и ја с оваковим прекрасним, невенућим и во вјеки миришућим цвећем конац књижице моје украсио? Примите, дакле, усердно љубими читатељи, умнога пролећа, из англијских садова и поља сасу, љубицу и лепу ружицу, и украшујте с њима срце, ум и душу вашу!”.

У Доситејевом цветнику налазимо жанровски карактеристичне просветитељске и образовне рубрике: басне са огледима пуним подука из разних области, поучних прича из класичне старине и из живота, као и народних пословица; аутобиографска поучна писма, алегоријске приче и сентенције, а наравоученија басни, својеврсни просветитељски и образовни огледи садрже читав жанровски спектар (песме, приче из класичне старине, приче из живота, дијалошке расправе, приказе књига).

Сви ови жанрови оставили су знатан траг у српској књижевности, без њих се не може у потпуности сагледати њена историја. Чворишна тачка за даље разграњавање ових жанрова, па и читаве новије српске књижевности, био је цветник Доситеја Обрадовића. 


\section{Културолошки контекст}

Без културолошког контекста епохе коју означавамо епохом просвећености не може се ваљано одговорити на питање зашто Скерлић предговор Орфелиновог Магазина сматра историјским и прекретничким, зашто Стојан Новаковић у својој Историји српске кюижевности управо овакав тип периодика, пре свега магазине и забавнике, сматра основом из које се српска књижевност почела даље и плодоносно гранати.

Епоха просвећености донела је и српској култури широко поимање појма писац и књижевност. Под овим појмовима подразумевали су се умни људи који су истовремено били и научници и књижевници, и преводиоци, и уредници, и књижари. Они су сакупљали и претплате за своје књиге и оглашавали их, по правилу били су власници првих приватних библиотека изабраних и преко потребних књига без којих нису кретали на дужи пут, о чему Доситеј сведочи у више наврата. То је најбоље уочила Мирјана Стефановић која је, у наше време, највише труда уложила да опише приватне појединачне библиотеке водећих Срба тог времена и која је, с разлогом, и једну од својих последњих књига посвећених изучавањима српске књижевности 18. и првих деценија 19. века насловила Библиотека српске књижевности.

Појам аутора је, посебно у 18. веку, тешко дефинисати. Појединци уређују периодичне публикације као ауторска дела, иако најчешће преводе и прерађују туђе текстове, баве се штампарским послом, скупљају пренумеранте, пишу објављенија, продају своја издања. Ауторство се највише огледа у прерадама и коментарима, општи царствујући жанр јесте оглед. Тако Доситеј преводи басне и прерађује их према потреби и нивоу свог национа, у наравоученијима даје огледе у којима налазимо жанровско обиље, у којима се жанрови претапају, покушава да буде актуелан, расправља о религији и њеној суштини, при чему у први план ставља врлине: љубав (према другима, без обзира на верску и расну припадност), добродјетель, рад на ползу народа, са протестантских позиција супротставља се институцијама цркве и клеру, бори се да разум и оно што се искуствено може доказати превлада у свести читалаца.

И појам књиге схватан је, тада, веома широко. Тек касније ће уследити лире, алманаси посвећени поезији, романи (мада су и они у почетку жанровски хибрид путописне, мемоарске и пустоловне прозе), књиге намењене земљеделцима, женама и сл. У том флуидном и активном жанровском шаренилу у којем је преовладавао тип публикације којој највише одговара одређење кюига за народ, преважну улогу одиграла је прва српска књижевна периодика, пре свега магазини, иветници, ковчежићи, забавници и 
алманаси који су као културолошка призма сажимали укупан културолошки контекст када је реч о писаној (штампаној) речи. У њима налазимо читав спектар хибридних и још неискристалисаних жанрова, по садржају они су својеврстан излог готово свих почетака и зачетака новије српске књижевности, служили су као стваралачки подстрек, преко прилагођених превода и детаљнијих коментара упознавали су још веома узак и „млад”, свакако недефинисан, аморфан и сталешки и по образовању нераслојен круг читалаца са оним што је у свету вредно, поучно и за просвећеност народа важно објављено у тадашњим европским културним средиштима. Њихово бављење издавалаштвом, посвећеност књизи, заснивало се на чврстом убеђењу да је неопходно ширење читалачког круга, да је то основни предуслов јачања културе сопственог народа. Зато се у првој српској периодици и књигама за народ аутори обраћају свима који читати знају, и бирају жанровско шаренило како би се књиге што боље примиле (магазин за свакога - од свачега понешто) и како би својом публикацијом обухватали што више људи. Управо тим напорима, бирањем одговарајућих тема и жанровских облика, они утврђују културолошки модел који у том времену одговара њиховом национу.

Иако се за поједине магазине, цветнике, забавнике могу утврдити чак и директни узори, које Доситеј, на пример, и не крије, или су налазили директне узоре у сопственој књижевној традицији, као што Вук Караџић, поред тога што се угледао на Ковчежић рајнског домаћег пријатељь Јохана Петера Хебела (1760-1826) и из њега преузимао чак и преводио приповетке за свој забавник Даницу, у предговору свог забавника издваја и календар и магазин Захарије Орфелина, који су, опет, имали свој узорник у руским сличним публикацијама - чак и поред свега тога треба истаћи да сви српски писци, умни Срби тог времена, у жељи да ваљано пораде на културолошком успону свог народа и његовом националном освешћивању, настоје да пронађу сопствени културолошки модел подобан српском национу. Истовремено, дубоко ослоњени на класичну и византијску традицију, водећи српски писци тог времена сагледавају културу свог народа као део јединственог простора. Орфелин прати значајне књиге које се објављују у Москви, Лењинграду, Бечу, Будиму, Лајпцигу, Венецији, у првом плану су му аутори словенског, посебно јужнословенског порекла; Доситеј простор шири на Немачку, Француску и Енглеску, са жељом да се Срби осете делом свеукупне светске културе; Јован Рајић пише историју Хрвата, Бугара и Срба, чак хибридним језиком како би његова историја могла да се чита на свим просторима где ти народи живе. 
Културолошка основа новог доба производ је прекретничког отварања и особитог раскида са средњовековном традицијом пре свега по томе што се тражи њено место у укупном светском културолошком поретку. И поред тематских и жанровских континуитета баштињених из средњовековне традиције пре свега захваљујући цркви (превагу имају верзије рукописа и преписивање утврђених текстова), а, понекад, одржаваних само усменим путем и захваљујући усменом ствралаштву, књижевност новог доба доноси нов начин коришћења писане речи за утврђивање сопственог национа и одређивање његовог места у далеко ширем културолошком простору. У овом културолошком преокрету велику улогу имали су истакнути појединци подржавани од стране европски признатих умова, пре свега из руских и грчких православних средишта, али ништа мањи и из западних, оних у којима превладава протестантски концепт поимања културе, па и религије (далеко ближи Србима од католичког концепта који их је, индиректно, преко унијаћења, и угрожавао). Притом треба имати на уму и значајну улогу масона који су и у малим народима, како су ступали на европску позорницу, налазили истакнуте појединце, подржавали их и надахњивали идејама, помагали издавање њихових књига чак и као мецене, усмеравали њихов рад. То траје и у првим деценијама 19. века, да поменем само плодоносну сарадњу Јернеја Копитара са Вуком Караџићем, али и представницима других словенских народа који су припадали аустријском царству, која је уродила многим првим речницима и граматикама језика малих словенских народа, описима фолклора појединих народа, првим преводима Библије захваљујући којима су многи словенски језици стицали статус признатог језика.

\section{Доситејев цветник}

Доситејево дело Басне значајно је као парадигматски периодик по жанровској разноврсности коју је, у почетку, намеравао да издаје у четири свеске (и Орфелинов Магазин је покренут са сличном намером, да читаоци сами склапају свеске у целину, али се свео само на прву част), па када му је штампар из Лајпцига, масон Јохан Готлиб Емануел Брајткопф омогућио да изда и повећу књигу, он је цео свој цветник проширио на 446 страница (склопио је целину тако да пагинација тече континуирано), убацујући у њега нове рубрике, са посебним уводницима, а у другом делу Живота и прикљученија писаном у облику писама налазимо и писма која је написао док се дело штампало (датирана су годином 1789. иако на насловној страници књиге стоји 1788). 
Када је реч о структури Доситејевог цветника најпре до изражаја долази спектар жанрова не само по рубрикама (одељцима), већ и у истом тексту. Уз басне иду приче о животињама, о митским животињама (Букефало Александра Македонског), поучне приче из зоологије (о крокодилу). У којој мери су басне биле доминирајући жанр у свести народа крајем 18. и почетком 19. века најбоље говори податак да од 160 басана које у свом цветнику објављује Доситеј, седамдесетак има мање-више одговарајуће варијанте међу 153 „народне басне” које је забележио у народу Вук Врчевић. Међу Доситејевим баснама налазимо и приче у којима су јунаци митске и значајне историјске личности, басне се већ у овом Доситејевом делу по структури приближавају анегдотама. Ова блискост басана и анегдота продужава се и до средине 19. века када Љубомир Ненадовић у Шумадинки под насловом „Две басне о Доситеју Обрадовићу” објављује анегдоте у којима налазимо чак и наравоученија. У Доситејевом цветнику мешају се, боље рећи прожимају митолошке приче и приче из класичне старине са анегдотама из савремене историје. То се, такође, наставља и у 19. веку, када значајно место у периодици заузимају и историјске личности из Првог српског устанка. У тежњи да јунаке Српске револуције повеже са класичном старином, да и српску повест укључи у светску историјску основу, у оно што је вредно општег памћења, Вук у Данищи описује Хајдук Вељка и пореди га са Ахилом и Милошем Обилићем: „У вријеме Ахила и Милоша Обилића он би заиста њиов друг био, а у његово вријеме Бог зна, би ли се они могли с њим испоредити."

Сваки од одабраних жанрова у Доситејевом цветнику има и истакнуту улогу у општем културолошком концепту за који се залаже. На пример животопис (аутобиограбска, мемоарска проза). У књизи Басне Доситеј доноси други део Живота и прикљученија користећи епистоларни жанр (у тадашњем маниру писма се упућују читаоцу појединцу - пријатель) са путописном основом. У овим писмима намењеним читаоцима Доситеј открива нове пределе и људе за које, често, српска јавност до тада није ни чула, са циљем да у свести свог народа превазиђе ретардирајућу бинарну опозицију свој-туђ, унапред стављање негативног предзнака када су у питању други.

Посебно значајну улогу одиграо је жанр житија. Послужио је као основа за промишљање и утврђивање националне и опште историје. Ту се најпре јављају монолитнија дела, попут Орфелинове књиге из 1772. Житије и славнија дела государја императора Петра Великаго или животописа Симеона Пишчевића и Георгија Арсенијевића Емануела (превео га и објавио Вук Караџић). Када је реч о историји посебну улогу имају и усмено предање и народна епска песма. Јован Рајић се у великој мери 
у својој Историји ослања на ове изворе, а историчар Стојан Новаковић је чак крајем 19. века народну песму сматрао важним историјским извором (ставља је на треће место после докумената и материјалних доказа), уз упозорење да се мора вешто и критички користити, са добрим познавањем усменог, народног начина памћења оног што је вредно да се пренесе потомцима. И потоња истраживања (Радован Самарџић, Ненад Љубинковић), показала су да се у епској народној песми находи суштина националне историје: однос народа према великашима, сопственој власти, према суседима и непријатељима. У њој се у преплету историјске и епске истине издваја непогрешиво оно (личности и догађаји) што заслужује да уђе у епску вертикалу, она је основа свеукупног романсирања историје у српској књижевности.

Кроз такву жанровску мрежу пулсирала је нова српска књижевност. Из тог жанровског тотала издвајали су се поједини жанрови као владајући, боље рећи најподеснији културолошком контексту. Тако Доситеј у први план уводи басне; у поезији једно време превладавају оде; у прози разглаголствија, разговори са мртвима на међупростору између овога и онога света, дијалози из Јелисијума, који протрајавају у српској књижевности све до средине 19. века када доживљавају пародијску деконструкцију; у првим периодичним публикацијама континуирано, све до средине 19. века, налазимо поучне и забавне приповетке и анегдоте.

Ако би се усредсредили на жанровски аспект публикација периодичног карактера намењених младима, кључно место заузимају басне објављене у Доситејевом цветнику Басне, али упоредо са њима и поучне повеснице, митолошке приче и приче из класичне старине, из ближе историје и из живота, као и анегдоте о познатим људима којима су прошарана његова наравоученија басни. Према томе којем су се жанру поучне прозе у 19. веку опредељивали уредници забавника, алманаха, листова и часописа, можемо издвојити две линије српске књижевне периодике: ону која је одржавала концепт класицистичког приступа и која се радије опредељује за басне и митолошке приче (Летопис, Голубица с иветом книжества србског, Бачка вила, Сербска пчела), те ону у којој су, уместо басана, објављиване претежно поучне повеснице, приче из класичне старине и новије историје (Забавник, Даница, Новине српске, Уранија, Српска зора, Сербска пчела). Овакав приступ отвара сасвим нове погледе на историју српске књижевности и омогућује да се утврди у којој мери историја појединих жанрова у периодици утиче на творење парадигматских система појединих књижевних епоха и праваца, колико је њихова судбина (настајање, развој, преструктурирање, њихова паро- 
дија, гашење) пресудна да историја књижевности буде таква каква јесте, боље речено, каква нам се чини.

Доситејев цветник Басне својеврсна је жанровска холограмска структура. У овој Доситејевој књизи магазинског типа, како сам вели цветнику, налазимо спектар жанрова идентичан жанровском спектру његових целокупних дела, почев од сентенција, поучних мисли које је као жанр неговао у својим првим списима (верзије Буквице, Ижица, Венац од алфавита). По томе је његов цветник истовремено и парадигматски модел ране наше периодике, а свакако и најадекватнији репрезент одабраног културолошког модела епохе просвећености у српској књижевности.

Из културолошког аспекта, веома је важан континуитет српске књижевне периодике који се кроз деценије наставља на Орефелинов Магазин и Доситејев цветник Басне. Да поменем Летопис Матище српске, посебно прву његову фазу магазинског типа, покренутог са пуном свешћу о значају Орфелиновог Магазина који је, најпре, уз примисао на цветник, требало да носи име Сербска пчела, Вукову Даницу која је у основи национални магазин првога реда, Сербску пчелу Павла Стаматовића, Голубицу с иветом книжества србског Јована Хаџића, Српско-далматински магазин који је тридесет година излазио у Задру и Загребу. Сва ова периодична гласила имају заједничку жанровску основу и програмску усмереност, свест о постојању претходника и стварању нове српске књижевности.

\section{ЛИТЕРАТУРА}

Деретић, Јован 1979: Алманаси Вуковог доба, Институт за књижевност и уметност - Вук Караџић, Београд.

Матицки, Миодраг 1997: Летопис српског народа. Три века алманаха и календара, Институт за књижевност и уметност - Библиотека Матице српске, Београд.

Матицки, Миодраг 2009: „Почеци српске књижевне критике”, Кюижевна историја, XLI, 137-138, стр. 105-111.

Обрадовић, Доситеј 2007: Сабрана дела Доситеја Обрадовића. Басне. Истина и прелест. Пут у један дан, књ. 2. Приредио Миодраг Матицки, Задужбина „Доситеј Обрадовић”, Београд.

Павић, Милорад 1969: Сабрана дела Вука Караиића. Даница 1826-18271828-1829; 1834: „О српским календарима - као предговор овој књизи" (стр. 523-525), Просвета, Београд. 
Скерлић, Јован 1909: Српска кюижевност у XVIII веку, Београд.

Стефановић, Мирјана Д. 2007: Библиотека српске кюижевности, Чигоја штампа, Београд.

Miodrag Maticki

THE BEGINNINGS OF THE SERBIAN LITERARY PERIODICALS. DOSITEJ'S "CVETNIK"

FABLES (LEIPZIG, 1788) IN THE CONTEXT OF THE PERIODICALS AND GENRE

Summary

In the development of the Serbian literary periodicals the key role was played by the first calendars compiled by Zaharije Orfelin, above all, his Slavonic-Serbian calendar of the Eastern church (Venice, 1766) and his Slavonic-Serbian journal (Venice, 1768). They were followed by "cvetnici" (collections of moral stories), entertainment magazines, almanacs, and anthologies with the characteristics of periodicals. Dositej's "cvetnik" Fables (1788), intended for the young, stood in the forefront, having all the typical educational sections: fables with moral comments, moral stories from classical antiquity and from life, folk proverbs, autobiographical letters with moral instructions, allegories, maxims, dialogical treaties and book reviews. All these genre forms left their considerable mark on Serbian literature and the subsequent literary periodicals. 